\title{
MACROECONOMIC DETERMINANTS OF ECONOMIC GROWTH: A REVIEW OF INTERNATIONAL LITERATURE
}

Themba G. Chirwa, Nicholas M. Odhiambo

\section{Abstract}

The paper conducts a qualitative narrative appraisal of the existing empirical literature on the key macroeconomic determinants of economic growth in developing and developed countries. Much as other empirical studies have investigated the determinants of economic growth using various econometric methods, the majority of these studies have not distinguished what drives or hinders economic growth in developing or developed countries. The study finds that the determinants of economic growth are different when this distinction is used. It reveals that in developing countries the key macroeconomic determinants of economic growth include foreign aid, foreign direct investment, fiscal policy, investment, trade, human capital development, demographics, monetary policy, natural resources, reforms and geographic, regional, political and financial factors. In developed countries, the study reveals that the key macroeconomic determinants that are associated with economic growth include physical capital, fiscal policy, human capital, trade, demographics, monetary policy and financial and technological factors.

Keywords: Economic Growth; Macroeconomic Determinants; Developing Countries; Developed Countries

JEL Classification: E13, 011, 047

\section{INTRODUCTION}

The investigation into the factors that increase or hinder economic growth has been one of the central tenets amongst theoretical and empirical growth researchers, but little consensus has been reached to date. Within the framework of economic growth theory, there have been two important novelties that have spearheaded much of the existing discussion on economic growth. These include neoclassical growth theory and endogenous growth theories. Their main focus has been on the importance of state factors such as the accumulation of physical capital and human capital development (see, among others, Solow 1956; Romer 1986; Lucas 1988). However, there have been other equally important contributions to economic growth literature that focus either on the impact of efficiency factors on economic growth (see Easterly and Wetzel 1989; Barro 1990; World Bank 1990; Barro and Sala-i-Martin 1992, among others) or on the importance of fundamental sources of economic growth, such as institutions and legal, demographic, geographic, socioeconomic and political factors (see Barro 1999, 2003; Sachs and Warner 1997; Burnside

\section{Themba G. Chirwa, MA}

Doctoral Candidate, Department of Economics University of South Africa, Pretoria, South Africa Email: tchirwa@gmail.com

\section{Prof Nicholas M. Odhiambo, PhD}

Professor of Economics, Department of Economics University of South Africa, Pretoria, South Africa Email: odhianm@unisa.ac.za 
and Dollar 2000; Radelet, Sachs, and Whang-Lee 2001, among others).

The neoclassical Solow-Swan (1956) economic growth theory, also known as the exogenous growth model, advocates for the accumulation of physical capital as an important driver of economic growth in the short run, while technological advancement is the key determinant of economic growth in the long run. An important extension of the neoclassical growth model was the inclusion of human capital stock as one of the key factors driving economic growth to complement physical capital accumulation (Mankiw, Romer, and Weil 1992; Islam 1995). In terms of endogenous growth theorists, their major contribution is based on the inclusion of productivity factors such as learning-by-doing and useful technological knowledge (research and development) as important drivers of economic growth (Romer 1986, 1990; Lucas 1988; Grossman and Helpman 1991; Aghion and Howitt 1992; Stokey 1995).

Much as there is consensus that state factors such as the accumulation of physical capital (investment) and human capital stock, on the one hand, and productivity factors (technological growth) on the other, are important macroeconomic determinants of economic growth in almost any country (Solow 1956; Frankel 1962; Romer 1986, 1990; Lucas 1988; Mankiw, Romer, and Weil 1992; Aghion and Howitt 1991; Grossman and Helpman 1992), there are other proponents who postulate that factors affecting the efficiency of savings and investment are equally important determinants in influencing economic growth (Easterly and Wetzel 1989; World Bank 1990; Fischer 1992). These efficiency factors became prominent in the 1990s, with three key outcomes being targeted: stability of the macro-economic environment; effectiveness of the institutional framework of an economy related to political and economic governance, incentive structures and social infrastructure; and the setting up of the right price mechanism and necessary regulatory environment to clear markets (World Bank 1990; Snowdon and Vane 2005).

As argued by Fischer (1992), the main reason why macroeconomic stability matters to economic growth is the uncertainty it creates with respect to the prediction of the future value of economic variables. One source is policy-induced uncertainty, which affects the efficiency of the price mechanism. If, for instance, the expectation is that inflation, government spending, real exchange rates, real interest rates and population growth will rise, these may have a negative influence on the future rate of economic growth. The second source is temporal uncertainty, where investors hold on to their investments until the macroeconomic environment has stabilized; if not controlled this may lead to capital flight (World Bank 1990; Barro 1990; Pindyck 1988; Pindyck and Somalino 1993).

Barro and Sala-i-Martin (1992), for example, have modelled the significance of government spending on economic growth and found that high government spending has a negative impact on economic growth. In another spectrum, efficiency factors such as inflation (Mundell 1963; Tobin 1965; Sidrauski 1967; Stockman 1981; Fischer 1983; Bruno and Easterly 1998), real exchange rate stability (Balassa 1964; Samuelson 1964; Dollar 1992; Rodrik 2008), foreign aid (Chenery and Strout 1966; Riddell 1987; Burnside and Dollar 2000), financial development or repression (McKinnon 1973; Shaw 1973), international trade (Dollar 1992; Knight, Loayza, and Villanueva 1993) and population growth (Solow 1956; Boserup 1996) have dominated much of the research, with little consensus being reached on their association with economic growth.

Inasmuch as a number of empirical studies have been conducted in order to identify the key determinants of economic growth, many growth economists have resorted to selecting as many determinants as possible, as long as there is enough pooled-country data and degrees of freedom to handle the analysis (Sala-i-Martin, Doppelhofer, and Miller 2004; Ciccone and Jarocinski 2010). This approach has been supported by studies that argue that the robustness of determinants can only be guaranteed by the inclusion of more determinants of economic growth (Salai-Martin, Doppelhofer, and Miller 2004; Bayraktar 2006). On the other hand, this approach provides a framework showing evidence that certain factors may behave in a dissimilar manner, which may be misleading to policy makers focusing on country-specific economic strategies.

Much as pooled data may provide a convenient analytical framework to determine the common determinants of economic growth, many governments do not know the key drivers of economic growth specific to their economies. The new literature on empirical growth research stresses the importance of how country-specific development plans and economic reforms can cause different equilibria, or time paths, for per capita income growth (Azariadis and Drazen 1990; Durlauf and Johnson 1995). Today it is still not clear as to which factors are the principal drivers of economic growth within and among countries.

The paper, therefore, aims to qualitatively review the existing empirical literature on the determinants of economic growth with a special focus on whether there is consensus amongst growth economists in terms of the key macroeconomic determinants that 
either drive or hinder economic growth. The paper differs fundamentally from previous studies, as it focuses on distinguishing the key macroeconomic determinants of economic growth that are relevant for developing and developed countries. This study is divided into six sections. Section 1 introduces the subject matter. Section 2 reviews the empirical evidence on the key macroeconomic determinants of economic growth in developing countries. Section 3 extends the analysis by investigating the key macroeconomic determinants of economic growth in developed countries. Section 4 focuses on the key macroeconomic determinants of economic growth specifically for South-Eastern and Central European Countries. Section 5 summarises the discussion. Lastly, section 6 concludes the research.

\section{DETERMINANTS OF ECONOMIC GROWTH IN DEVELOPING COUNTRIES}

In this section, we examine fourteen (14) empirical growth studies that focused their analysis on identifying the key macroeconomic determinants of economic growth in developing countries. The studies include Dollar (1992), Fischer (1992), Knight, Loayza, and Villanueva (1993), Most and Vann de Berg (1996), Easterly and Levine (1997), Hamilton and Monteagudo (1998), Barro (1999, 2003), Burnside and Dollar (2000), Chen and Feng (2000), Radelet, Sachs, and Whang-Lee (2001), Bhaskara-Rao and Hassan (2011), Chang and Mendy (2012), and Anyanwu (2014). The econometric methodologies adopted in these studies include cross-country, panel and single-country regressions.

Dollar (1992) investigated the sources of economic growth in 95 developing countries, covering the period 1976-1985. Using a cross-sectional regression analysis, the study results showed that real exchange rate variability and the index of real exchange rate distortion were negatively and significantly associated with long-run economic growth: the investment rate was positively and significantly associated with economic growth. In addition, the study found that the higher the degree of exchange rate instability, the lower the degree of technological diffusion from advanced economies (Dollar 1992). The study, therefore, concluded that outward-orientation plays an important role in accelerating technological development in an economy: this is achieved through a low degree of protection and a stable real exchange rate regime.

Fischer (1992) investigated macroeconomic stability and economic growth in Sub-Saharan Africa (SSA) and Latin America and the Caribbean (LAC) countries during the period 1970-1985. Using a cross-section regression, the study results revealed that human capital, investment, and budget surplus were positively and significantly associated with economic growth, while initial real GDP, inflation and dummy variables for SSA and LAC were negatively and significantly associated with economic growth. He therefore concluded that a reasonable level of macroeconomic stability is necessary for sustained economic growth.

Knight, Loayza, and Villanueva (1993) extended the Mankiw, Romer, and Weil (1992) model by examining the relationship between investment, human capital, public investment and outward-oriented trade policies on economic growth in 98 countries. Using a panel regression method and two sub-samples of 81 countries and 59 developing countries, their study showed a strong and positive correlation between physical capital, human capital and economic growth in both sub-samples. The results also showed public investment to be positively and significantly associated with economic growth in developing countries. The weighted tariffs as a measure of trade openness and population growth were both negatively and significantly associated with economic growth in both sub-samples (Knight, Loayza, and Villanueva 1993). The study concluded that physical capital, human capital, public investment, openness to trade, and population growth were all important determinants of economic growth.

Most and Vann de Berg (1996) investigated the determinants of economic growth in eleven SubSaharan Africa countries using country-specific time series growth models. The study results revealed mixed results. Foreign aid was found to be negatively and significantly associated with economic growth in Togo, Ivory Coast, Nigeria, Zambia, Rwanda, and Botswana: on the other hand it was positively and significantly associated with economic growth in Niger, Senegal and Mauritius. Domestic savings were found to be positively and significantly associated with economic growth in Togo, Senegal, Ivory Coast, Nigeria, Cameroon, and Kenya, but negatively and significantly associated with economic growth in Mauritius and Zambia. Foreign Direct Investment was positively and significantly associated with economic growth in Ivory Coast, Niger, Kenya and Togo, but negatively and significantly associated with economic growth in Mauritius and Rwanda. Finally, population growth was only found to be negatively and significantly associated with economic growth in Senegal, Mauritius and Niger.

Easterly and Levine (1997), using an empirical cross-sectional growth equation, investigated the determinants of economic growth in Sub-Saharan Africa and Latin America and Caribbean Countries during 
the periods 1960, 1970 and 1980. The study found the logs of schooling, financial depth, a measure of telephones per worker, and fiscal surplus were positively and significantly associated with economic growth, while political assassinations and black market premiums were negatively and significantly associated with economic growth. All dummy variables were negative and significantly associated with economic growth, showing that Sub-Saharan African countries and Latin America and Caribbean countries experienced slow economic growth. Furthermore, the study results revealed that Africa's poor growth was associated with low schooling, political instability, underdeveloped financial systems, distorted foreign exchange markets, high government deficits, and insufficient infrastructure. The study concluded that budget deficits, black market premiums, financial depth, political stability, infrastructure, and human capital development accounted for a substantial amount of cross-country variation in economic growth rates (Easterly and Levine 1997).

Hamilton and Monteagudo (1998), using leastsquares regression, re-examined the Mankiw, Romer, and Weil (1992) empirical model, using data covering the period 1960-1985. The variables included were changes in the rate of physical investment, the average percentage of the working age population that was in secondary school, and the average annual rate of growth of the working age population for that country between 1960 and 1970 . They found that changes in output growth were positively and significantly associated with changes in the rate of physical investment. However, changes in human capital development were negatively and significantly associated with economic growth. They also found that the coefficient on the change in population growth was not statistically significant (Hamilton and Monteagudo, 1998, p. 500).

Barro (1999) investigated the determinants of economic growth using an extended neoclassical growth model for 100 countries and covering the period 1960-1995. Based on a panel regression and three stage least squares method, the study results showed that investment share, growth rate of terms of trade, years of schooling, rule of law index, democracy index and international openness were positively and significantly associated with economic growth, while government consumption, total fertility rate, and inflation were negatively and significantly associated with economic growth.

Burnside and Dollar (2000) investigated the relationship between foreign aid, policies and economic growth in 56 developing countries comprising 16 middle-income and 40 low-income countries. Using a two-stage least squares (2SLS) method, the results showed that foreign aid was positively and significantly associated with economic growth when it entered the growth regression as an interactive term with policy: however, foreign aid was found to have no influence on economic growth without this term in the countries studied. On the other hand, the results showed that budget surpluses, institutional quality, trade openness and countries situated in East Asia were positively and significantly associated with economic growth. In addition, the results revealed that political assassinations, inflation and countries located in SSA were negatively and significantly associated with economic growth.

Chen and Feng (2000) investigated the relationship between trade (exports plus imports) as a share of real GDP, state-owned enterprises, inflation, investment, higher education enrolment and economic growth in China. Using provincial panel data, the study found trade and university enrolment to be positively and significantly associated with the annual average rate of per capita GDP. Inflation and state-owned enterprises, on the other hand, were negatively and significantly associated with economic growth. Their study concluded, therefore, that private enterprises, foreign trade and education were important determinants of China's long-run economic growth.

Covering the period 1965-1990, Radelet, Sachs, and Whang-Lee (2001) investigated the determinants of economic growth in 18 Asian countries. Using an extended neoclassical cross-country growth model, the study results revealed that initial education attainment, coastline distance to land area, government savings, trade openness, quality of institutions, life expectancy and the growth of the working age population were positively and significantly associated with economic growth: on the other hand initial output per worker, natural resource abundance, landlockedness, and location in the tropics were negatively and significantly associated with economic growth.

In another study, Barro (2003) investigated the determinants of economic growth in a panel of 87 countries that covered both developed and developing countries during the period 1965-1995. The study results were based on three cross-section growth regressions that covered the periods 1965-1975; 1975 1985; and 1985-1995. The results revealed that average years of school attainment, investment, and the rule of law, democracy, trade openness, and terms of trade were all positively and significantly associated with economic growth, while initial level of per capita GDP, life expectancy, fertility rate, government consumption, inflation rate and landlockedness were negatively and significantly associated with economic growth. 
Bhaskara-Rao and Hassan (2011) investigated the determinants of long-run economic growth in Bangladesh covering the period 1970-2007. Based on an Autoregressive Distributed Lag method, the study results revealed that the implementation of reforms since the 1980s, FDI, money supply, and trade openness were positively and significantly associated with economic growth, while government expenditure and inflation were negatively and significantly associated with economic growth.

Chang and Mendy (2012) investigated the empirical relationship between openness and economic growth in 36 African countries during the period 19802009. Using a panel fixed effects regression model, the study results revealed that foreign aid, exports, imports, labour employed and trade openness were positively and significantly associated with economic growth: however, foreign direct investment, domestic investment, and gross national savings were negatively and significantly associated with economic growth. The study also found that foreign aid exhibited mixed results when disaggregated by region. In the Middle and North Africa regions, foreign aid was positively and significantly associated with economic growth; while in the West and East Africa regions foreign aid was negatively and significantly associated with economic growth.

Finally, Anyanwu (2014) examined the factors affecting economic growth in Africa and China using an empirical growth model. Applying cross-country panel data for African countries covering the period 19962010 together with time series data for the 1984-2010 period for China, the study results showed that for Africa higher domestic investment, net official aid, secondary school enrolment, metal price index, government effectiveness (governance) and urban population were positively and significantly associated with economic growth. In China, using a subset of the regressors, the study results showed that domestic investment and trade openness were positively and significantly associated with economic growth, while official development aid, population growth, inflation, credit to the private sector, agricultural material price, and oil price indices were negatively and significantly associated with economic growth.

\section{DETERMINANTS OF ECONOMIC GROWTH IN DEVELOPED COUNTRIES}

In this section, the key macroeconomic determinants for developed economies are examined in seven empirical growth studies. These include Bleaney, Gemmell, and Kneller (2001), Freire-Seren (2002),
Anaman (2004), Acikgoz and Mert (2005), Bayraktar (2006), Asheghian (2009) and Checherita-Westphal and Rother (2012). The methodological approach adopted in these studies was also mixed and included cross-country, panel and single-country regressions.

Bleaney, Gemmell, and Kneller (2001) used annual data from 22 developed countries covering the period 1970-1995, to investigate the relationship between fiscal policies and long-run economic growth. The study results showed that productive government expenditure had a significant and positive association with the long-run economic growth rate: distortionary taxes, on the other hand, had a negative and significant association with the long-run economic growth rate (Bleaney, Gemmell, and Kneller 2001). The study concluded that productive fiscal expenditures increased economic growth, while distortionary fiscal policies reduced economic growth.

Freire-Seren (2002) investigated the relationship between human capital accumulation and economic growth in Spanish regions using an augmented neoclassical growth model covering the period 19641991. The study found both human capital development and investment to be positively and significantly associated with economic growth.

Anaman (2004), covering the period 1971-2001, investigated the determinants of economic growth in Brunei Darussalam using an augmented neoclassical growth model. The results showed that exports and investment share were positively and significantly associated with real GDP growth. The study results also showed that government size exhibits threshold effects, with moderate government size being positively and significantly associated with economic growth, while higher government size was negatively and significantly associated with economic growth.

Acikgoz and Mert (2014), using an autoregressive distributed lag and Fully Modified Ordinary Least Squares method, investigated the relationship between investment and real GDP per capita in three Asian countries - Hong Kong, the Republic of Korea, and Taiwan. Using time series data covering the period 1951-2007 for Taiwan, 1953-2007 for Republic of Korea, and 1960-2007 for Hong Kong, the study results showed that in the short run, the investment share was positively and significantly associated with economic growth. In addition, it was positively and significantly related to the level of real GDP per capita in the long run. These findings proved consistent in all three countries.

Bayraktar (2006) investigated the robustness of the correlation between per capita growth rates and select macroeconomic indicators in Turkey using an Extreme Bounds Analysis covering the period 1968-1998. The 
results revealed that state variables that were robustly correlated with economic growth included the investment share and human capital development, which were positively and significantly associated with economic growth. In terms of monetary indicators, the study found a robust negative and significant correlation between inflation and economic growth. The study, therefore, concluded that investment, human capital development and inflation were robust determinants of economic growth in Turkey.

Asheghian (2009) employed an augmented neoclassical growth model to investigate the determinants of economic growth in Japan covering the period 19712006. Using a Beach-Mackinnon technique, the study results showed that the growth rates of total factor productivity and domestic investment were positively and significantly associated with economic growth.

Checherita-Westphal and Rother (2012) examined the relationship between high government debt and economic growth in 12 Euro countries using a conditional convergence equation and covering the period 1970-2008. Using per capita GDP growth rate as the dependent variable, the results revealed that government balance, private savings, and trade openness were positively and significantly associated with economic growth; while population growth and real interest rates were negatively and significantly associated with economic growth. Government debt was found to be positively and significantly associated with economic growth, while the square of government debt was negatively and significantly associated with economic growth, confirming threshold effects.

Hamilton and Monteagudo (1998), using leastsquares regression, re-examined the Mankiw et al. (1992) empirical model, using data covering the period 1960-1985. The variables included were changes in the rate of physical investment, the average percentage of the working age population that was in secondary school, and the average annual rate of growth of the working age population for that country between 1960 and 1970. They found that changes in output growth were positively and significantly associated with changes in the rate of physical investment. However, changes in human capital development were negatively and significantly associated with economic growth. They also found that the coefficient on the change in population growth was not statistically significant (Hamilton and Monteagudo 1998, p. 500).

Barro (1999) investigated the determinants of economic growth using an extended neoclassical growth model for 100 countries and covering the period 1960-1995. Based on a panel regression and three stage least squares method, the study results showed that investment share, growth rate of terms of trade, years of schooling, rule of law index, democracy index and international openness were positively and significantly associated with economic growth, while government consumption, total fertility rate, and inflation were negatively and significantly associated with economic growth.

In another study, Barro (2003) investigated the determinants of economic growth in a panel of 87 countries that covered both developed and developing countries during the period 1965-1995. The study results were based on three cross-section growth regressions that covered the periods 1965-1975; 19751985; and 1985-1995. The results revealed that average years of school attainment, investment, and the rule of law, democracy, trade openness, and terms of trade were all positively and significantly associated with economic growth, while initial level of per capita GDP, life expectancy, fertility rate, government consumption, inflation rate and landlockedness were negatively and significantly associated with economic growth.

\section{DETERMINANTS OF ECONOMIC GROWTH IN SOUTH-EASTERN AND CENTRAL EUROPEAN COUNTRIES}

This section investigates the key macroeconomic determinants of economic growth for South-Eastern and Central European economies. The four empirical studies that are examined include: Botric and Slijepcevic (2008), De Grauwe and Schnabl (2008), Prochniak (2011) and Fetahi-Vehapi, Sadiku, and Petkovski (2015).

Botric and Slijepcevic (2008) investigated the association between banking sector efficiency and economic growth in six South-Eastern European countries, namely: Albania, Bosnia and Herzegovina, Bulgaria, Croatia, Macedonia and Romania during the period 1995-2005. Using a panel fixed effects regression estimation method, the study found that inflation and interest rate spread (defined as the margin between lending and deposit rates) were negatively and significantly associated with economic growth. Conversely, general government balance as a percentage of GDP was positively and significantly associated with economic growth.

De Grauwe and Schnabl (2008), on the other hand, investigated the impact of exchange rate stability on economic growth in 18 South-Eastern and Central European countries during the period 1994-2004. Using a panel fixed effects regression method, the study found that the exchange rate index against the Euro and the exchange rate index against the Euro 
and the US Dollar were negatively and significantly associated with output growth. They concluded that exchange rate stability promotes economic growth in these countries. Conversely, the study found that the growth rate of dollar exports and budget deficits as a percentage of GDP were positively and significantly associated with economic growth.

Prochniak (2011) investigated both demand- and supply-side determinants of economic growth in 10 Central and Eastern European economies during the period 1993-2009. Using an ordinary least squares estimation, the study found that the key economic growth determinants that were positively and significantly associated with economic growth in the selected countries included investment rate, human capital development, financial sector development, high services share in GDP, high share of working age population, development of information, communication and technology (ICT), high private sector share in GDP, economic freedom, and progress in market and structural reforms. Budget deficits, public debt, interest rates, and inflation were negatively and significantly associated with economic growth.

Fetahi-Vehapi, Sadiku, and Petkovski (2015) investigated the impact of trade openness on economic growth in 10 South-Eastern European countries during the period 1996-2012. Using additional regressors as control variables, the study found that trade openness, the initial level of GDP per capita, human capital development, gross fixed capital formation, and foreign direct investment were positively and significantly associated with economic growth; while population was negatively and significantly associated with economic growth when a fixed effects panel regression estimation method was used.

\section{DISCUSSION}

Table 1 summarises the findings of the study. The overall study results show that physical capital is largely positive and significantly associated with economic growth (Dollar 1992; Fischer 1992; Knight, Loayza, and Villanueva 1993; Hamilton and Monteagudo 1998; Barro 1999, 2003; Bleaney, Gemmell, and Kneller 2001; Anaman 2004; Acikgoz and Mert 2014; Bayraktar 2006; Prochniak 2011; Checherita-Westphal and Rother 2012; Anyanwu 2014; Fetahi-Vehapi, Sadiku, and Petkovski 2015). In some cases, the results also show that in developing countries investment can be negatively and significantly associated with growth (Most and Vann de Berg 1996; Chang and Mendy 2012).

In terms of human capital development, the empirical literature reviewed in this study shows that human capital development is positively and significantly associated with economic growth (Fischer 1992; Knight, Loayza, and Villanueva 1993; Easterly and Levine 1997; Chen and Feng 2000; Radelet, Sachs, and Whang-Lee 2001; Freire-Seren 2002; Bayraktar 2006; Anyanwu 2014). However, in some cases human capital development was found to be negatively and significantly associated with economic growth (Hamilton and Monteagudo 1998). These results are similar in both developing and developed economies. Much as most empirical studies have investigated the relationship between human capital development and economic growth, a meta-analysis of this relationship has confirmed that indeed this relationship is not homogeneous, with variations due to different factors (Benos and Zotou 2014).

Fiscal policy variables commonly used in the empirical growth literature cited in this study include budget surplus, tariffs, government expenditure, institutional quality, government effectiveness, and stateowned enterprises. The empirical results revealed that productive fiscal policies proxied by fiscal surplus, government savings, and the quality of institutions are positively and significantly associated with economic growth (Fischer 1992; Easterly and Levine 1997; Sachs and Warner 1997; Burnside and Dollar 2000; Bleaney, Gemmell, and Kneller 2001; Radelet, Sachs, and Whang-Lee 2001; Checherita-Westphal and Rother 2012; Anyanwu 2014). On the other hand, distortionary fiscal policies proxied by fiscal deficits, distortionary taxation, government consumption, and state-owned enterprises are negatively and significantly associated with economic growth (Knight, Loayza, and Villanueva 1993; Barro 1999, 2003; Chen and Feng 2000; Bleaney, Gemmell, and Kneller 2001; Bhaskara-Rao and Hassan 2011). These results are also similar across countries. However, the effect of fiscal policies on economic growth have been found to be weak and subject to the econometric methodology adopted (Nijkamp and Poot 2004).

The relationship between trade related variables and economic growth is also mixed and similar across countries. The proxies that have been investigated include real exchange rates, black market exchange rate premiums, trade openness, exports, imports and terms of trade. The empirical results revealed that trade openness, exports and imports are positively and significantly associated with economic growth (Fischer 1993; Sachs and Warner 1997; Barro 1999, 2003; Burnside and Dollar 2000; Chen and Feng 2000; Radelet, Sachs, and Whang-Lee 2001; Bhaskara-Rao and Hassan 2011; Chang and Mendy 2012; ChecheritaWestphal and Rother 2012; Anyanwu 2014). On the other hand, the real exchange rate and black market 
exchange rate premiums are negatively and significantly associated with economic growth (Dollar 1992; Easterly and Levine 1997; De Grauwe and Schnabl 2008). Terms of trade, on the other hand, show mixed results (Dollar 1992; Fischer 1993; Easterly and Levine 1997).

Demographic factors studied in the empirical growth literature include population growth, growth of the working age population, labour employed, labour force, and the fertility rate. Some studies found population, population growth, and labour employed to be positively and significantly associated with growth (Sachs and Warner 1997; Radelet, Sachs, and Whang-Lee 2001; Chang and Mendy 2012; Anyanwu 2014). Others however have found a negative and significant relationship between population, population growth, and the fertility rate (Most and Vann de Berg 1996; Hamilton and Monteagudo 1998; Barro 1999, 2003; Checherita-Westphal and Rother 2012; Anyanwu 2014). The results have also been confirmed in a meta-analysis between population growth and economic growth, where the effect depends on the variables included in the model (resource dilution and interaction effects) and econometric methodology adopted (Headley and Hodge 2009).

Exogenous factors that were commonly investigated in the empirical literature include foreign aid and foreign direct investment. The empirical literature revealed mixed results, with foreign aid and foreign direct investment either positively or negatively associated with economic growth. Most and Vann de Berg (1996), Chang and Mendy (2012) and Anyanwu (2014) found foreign direct investment and foreign aid to be negatively and significantly associated with economic growth. On the other hand, foreign direct investment and foreign aid were also found to be positively and significantly associated with economic growth (Most and Vann de Berg 1996; Burnside and Dollar 2000; Bhaskara-Rao and Hassan 2011; Chang and Mendy 2012; Anyanwu 2014). These determinants were found to be particularly important for developing countries. A meta-regression analysis on aid ineffectiveness, however, has confirmed that aid does not generate economic growth (Doucouliagos and Paldam 2011) supporting the negative association between the two variables.

Monetary policy or macroeconomic stability variables investigated in the empirical growth studies include inflation and money supply. The results revealed that in most cases inflation is negatively and significantly associated with economic growth (Fischer 1992; Barro 1999, 2003; Burnside and Dollar 2000; Chen and Feng 2000; Botric and Slijepcevic 2008; Bhaskara-Rao and Hassan 2011; Bayraktar 2006; Anyanwu 2014). The results are generally similar regardless of whether the countries studied are from developing or developed countries. However, a meta-analysis on this relationship would determine the robustness of the results and should be an area for future research.

The other category of sources of economic growth that include political factors, natural resources, geographic factors, reforms, and financial and regional factors also provide mixed results. Political variables investigated in this paper include rule of law, democracy, political assassinations, coups, and civil wars. The results showed that democracy and the rule of law were positively and significantly associated with economic growth (Barro 1999, 2003), while political assassinations, coups, and civil wars were negatively and significantly associated with economic growth (Easterly and Levine 1997; Burnside and Dollar 2000). A meta-analysis on the positive effects of institutions has been confirmed by Efendic, Pugh, and Adnett (2011); however, a meta-analysis of the effect of democracy on economic growth has been found to be indirect through human capital development, lower inflation, political stability and higher levels of economic freedom (Doucouliagos and Ulubasoglu 2008).

Natural resource variables used in the empirical growth literature include natural resource abundance or exports. The results showed that countries that relied on natural resources experienced lower economic growth (Sachs and Warner 1997; Radelet, Sachs, and Whang-Lee 2001). These results are applicable for both developing and developed countries. However, a meta-analysis on this relationship has found that the relationship between natural resource abundance and economic growth depend on a number of factors that include the levels of investment, institutional quality, distinction between natural resource types and resource dependence (Havranek, Horvath, and Zeynalov 2016).

The financial indicators investigated include financial depth, credit to the private sector and real interest rates. The results showed that financial depth was positively and significantly associated with economic growth (Easterly and Levine 1997), while credit to the private sector and real interest rates were negatively and significantly associated with economic growth (Checherita-Westphal and Rother 2012; Anyanwu 2014). However, a meta-analysis on the relationship of financial indicators and economic growth, though positive, has been found to be statistically weak (Bumann, Hermes and Lensink 2013).

Geographic factors investigated in the empirical growth literature include landlockedness, countries in the tropics, and those along the coastline. The study results revealed that countries that were landlocked 
and situated in the tropics experienced low economic growth (Sachs and Warner 1997; Radelet, Sachs, and Whang-Lee 2001; Barro, 2003), while countries along the coastline experience high growth (Radelet, Sachs, and Whang-Lee 2001). Some of the reform variables investigated in the empirical literature included the implementation of policy reforms, where the results revealed a positive association with economic growth (Bhaskara-Rao and Hassan 2011; Prochniak 2011). Lastly, countries in Sub-Saharan Africa and Latin and Caribbean countries have been found to experience low economic growth compared to countries in other regions (Fischer 1992; Easterly and Levine 1997); while countries in Asia experience high economic growth compared to other regions (Burnside and Dollar 2000). The importance of these factors on economic growth could benefit a great deal from future studies that carry out a meta-analysis to examine the size of their effects on economic growth.

\section{CONCLUSION}

In this study, the key macroeconomic determinants of economic growth in developing and developed economies are investigated by qualitatively surveying previous empirical studies. The paper aims to assess whether there is consensus amongst growth economists in terms of the key macroeconomic determinants that either drive or hinder economic growth in developing and developed economies. The paper differs fundamentally from previous studies by focusing on distinguishing the key macroeconomic determinants of economic growth that are relevant for developing and developed countries. A general overview of the empirical studies investigated in this paper reveal that the key macroeconomic determinants that are significantly associated with economic growth in developing countries, based on the order of their importance, include exogenous factors (foreign aid and foreign direct investment), fiscal policy, trade, physical capital, human capital, demographics, monetary policy, natural resources and geographic, regional, political and financial factors. In developed countries, the study reveals that the key macroeconomic determinants significantly associated with economic growth include physical capital, fiscal policy, human capital, trade, demographics, monetary policy and financial and technological factors.

However, while these studies reveal the key macroeconomic determinants of economic growth in developing and developed economies, the size of their effects on economic growth are different from study to study. In particular, there are some determinants, such as foreign aid, population growth, human capital development, fiscal policy variables, geographic location, and reforms, among others, that show mixed results. This suggests that the genuine growth effects of these determinants are not homogeneous between economies. Thus, building on one of the limitations of this study, a more pragmatic approach would be to apply meta-regression analysis or quantitative techniques to investigate the quantum effects of the determinants of economic growth, especially those that reveal mixed results. According to Roberts (2005), a meta-regression analysis is a method that objectively seeks to explain and quantify the differences between estimates obtained from a set of empirical studies. Thus, future research on the examination of the determinants of economic growth should focus on using meta-regression analysis techniques.

\section{REFERENCES}

Acikgoz, S., and Mert, M. 2014. Sources of Growth Revisited: The importance of the nature of technological progress. Journal of Applied Economics 17 (1): 31-62.

Aghion, P. and Howitt, P. 1992. A Model of Growth through Creative Destruction. Econometrica 60 (2): 323-351.

Anaman, K. A. 2004. Determinants of Economic Growth in Brunei Darussalam. Journal of Asian Economics 15 (4): 777-796.

Anyanwu, J. C. 2014. Factors Affecting Economic Growth in Africa: Are there any lessons from China? African Development Review 26 (3): 468-493.

Asheghian, P. 2009. Determinants of Economic Growth in Japan: The role of foreign direct investment. Global Economy Journal 9 (3): 1-9.

Azariadis, C. and Drazen A. 1990. Threshold Externalities in Economic Development. The Quarterly Journal of Economics 105 (2): 501-526.

Balassa, B. 1964. The Purchasing-Power Parity Doctrine: A reappraisal. Journal of Political Economy 72 (6): 584-596.

Barro, R. J. 1990. Government Spending in a Simple Model of Endogenous Growth. Journal of Political Economy 98 (5): S103-S125.

Barro, R. J. 1999. Determinants of Economic Growth: Implications of the Global Evidence for Chile. Cuadernos de Economía 36 (107): 443-478.

Barro, R. J. 2003. Determinants of Economic Growth in a Panel of Countries. Annals of Economics and Finance 4: 231-274.

Barro, R.J., and Sala-i-Martin, X. 1992. Public Finance in Models of Economic Growth. The Review of Economic Studies 59 (4): 645-661.

Bayraktar, B. 2006. Investigation on Sources of Growth for Turkey. Canadian Journal of Development 27 (1): 25-38. 
Benos, N, and Zotou, S. 2014. Education and Economic Growth: A meta-regression analysis. World Development 64: 669-689.

Bhaskara-Rao, R., and Hassan, G. 2011. Determinants of the Long-Run Growth Rate of Bangladesh. Applied Economics Letters 18: 655-658.

Bleaney, M., Gemmell N., and Kneller, R. 2001. Testing the Endogenous Growth Model: Public expenditure, taxation, and growth over the long-run. Canadian Journal of Economics 34 (1): 36-57.

Boserup, E. 1996. Development Theory: An analytical framework and selected application. Population and Development Review 22 (3): 505-515.

Bruno, M., and Easterly, W. 1998. Inflation Crises and LongRun Growth. Journal of Monetary Economics 41: 3-26.

Bumann, S, Hermes, N., and Lensink, R. 2013. Financial Liberalization and Economic Growth: A meta-analysis. Journal of International Money and Finance 33: 255-281.

Burnside, C., and Dollar, D. 2000. Aid, Policies, and Growth. The American Economic Review 90 (4): 847-868.

Chang, C., and Mendy, M. 2012. Economic Growth and Openness in Africa: What is the empirical relationship? Applied Economics Letters 19 (18): 1903-1907.

Checherita-Westphal, C., and Rother, P. 2012. The Impact of High Government Debt on Economic Growth and its Channels: An empirical investigation for the Euro area. European Economic Review 56: 1392-1405.

Chen, B. and Feng Y. 2000. Determinants of Economic Growth in China: Private enterprise, education, and openness. China Economic Review 11: 1-15.

Chenery, H. B., and Strout, A. M. 1966. Foreign Assistance and Economic Development. The American Economic Review 56 (4): 679-733.

Ciccone, A. and Jarocinski, M. 2010. Determinants of Economic Growth: will data tell? American Economic Journal: Macroeconomics 2 (4): 222-246.

Dollar, D. 1992. Outward-Oriented Developing Economies Really do Grow more rapidly: Evidence form 95 LDCs, 1976-1985. Economic Development and Cultural Change 40 (3): 523-544.

Doucouliagos, H., and Paldam, M. 2011. The Ineffectiveness of Development Aid: An update. European Journal of Political Economy 27 (2): 399-404.

Doucouliagos, H., and Ulubasoglu, M. A. 2008. Democracy and Economic Growth: A meta-analysis. American Journal of Political Science 52 (1): 61-83.

Durlauf, S. N. and Johnson, P. A. 1995. Multiple Regimes and Cross-Country Growth Behaviour. Journal of Applied Economics 10 (4): 365-384.

Easterly, W. R., and Wetzel, D. L. 1989. Policy Determinants of Growth: Survey of theory and evidence. Policy, Planning and Research Working Papers Series No. 343, Washington D. C., World Bank: 1-41.
Easterly, W. R., and Levine, R. 1997. Africa's Growth Tragedy: Policies and ethnic divisions. The Quarterly Journal of Economics 112 (4): 1203-1250.

Efendic, A., Pugh, G., and Adnett, N. 2011. Institutions and Economic Performance: A meta-regression analysis. European Journal of Political Economy 27 (3): 586-599.

Fetahi-Vehapi, M, Sadiku, L, and Petkovski, M. 2015. Empirical Analysis of the effects of Trade Openness on Economic Growth: An evidence of South East European countries. Procedia Economics and Finance 19: 17-26.

Fischer, S. 1983. Inflation and Growth. NBER Working Paper Series No. 1235: 1-22.

Fischer, S. 1992. Macroeconomic Stability and Growth. Cuadernos de Economía 29 (87): 171-186.

Frankel, M. 1962. The Production Function in Allocation and Growth: A synthesis. The American Economic Review 52 (5): 996-1022.

Freire-Seren, M. J. 2002. On the Relationship between Human Capital Accumulation and Economic Growth. Applied Economic Letters 9 (12): 805-808.

Grossman, G. M. and Helpman, E. 1991. Quality Ladders in the Theory of Growth. The Review of Economic Studies 58 (1): 43-61.

Hamilton, J. D. and J. Monteagudo. 1998. The Augmented Solow Model and the Productivity Slowdown. Journal of Monetary Economics 42 (3): 495-509.

Havranek, T., Horvath, R., and Zeynalov, A. 2016. Natural Resources and Economic Growth: A meta-analysis. World Development 88: 134-151.

Headley, D. D., and Hodge, A. 2009. The Effect of Population Growth on Economic Growth: A meta-regression analysis on the macroeconomic literature. Population and Development Review 35 (2): 221-248.

Islam, N. 1995. Growth Empirics: A panel data approach. The Quarterly Journal of Economics 110 (4): 1127-1170.

Knight, M., Loayza N. and Villanueva D. 1993. Testing the Neoclassical Theory of Economic Growth: A panel data approach. Staff Papers (International Monetary Fund) 40 (3): 512-541.

Lucas, R.E. Jr. 1988. On the Mechanics of Economic Development". Journal of Monetary Economics 22: 3-42.

Mankiw, N. G., Romer, D., and Weil, D. N. 1992. A Contribution to the Empirics of Economic Growth. Quarterly Journal of Economics 107 (2): 407-437.

McKinnon, R. I. 1973. Money and Capital in Economic Development. Washington, D.C. The Brookings Institution.

Most, S. J., and Vann de Berg, H. 1996. Growth in Africa: Does the source of investment financing matter? Applied Economics 28 (11): 1427-1433.

Mundell, R. 1963. Inflation and Real Interest Rate. Journal of Political Economy 71 (3): 280-283. 
Nijkamp, P., and Poot, J. 2004. Meta-Analysis of the Effect of Fiscal Policies on Long-Run Growth. European Journal of Political Economy 20 (1): 91-124.

Pindyck, R. S. 1988. Irreversible Investment, Capacity Choice, and the Value of the Firm. The American Economic Review 78 (5): 969-985.

Pindyck, R. S., and Somalino A. 1993. Economic Stability and Aggregate Investment. NBER Macroeconomics Annual 8: 259-318.

Radelet, S., Sachs, J. and Whang-Lee, J. 2001. The Determinants and Prospects of Economic Growth in Asia. International Economic Journal 15 (3): 1-29.

Riddell, R. 1987. Foreign Aid Reconsidered. Baltimore: Johns Hopkins University Press.

Roberts, C. J. Issues in Meta-Regression Analysis. Journal of Economic Surveys 19 (3): 295-298.

Rodrik, D. 2008. The Real Exchange Rate and Economic Growth. Brookings Papers on Economic Activity, Brookings Institute Press.

Romer, P.M. 1986. Increasing Returns and Long-Run Growth. Journal of Political Economy 94 (5): 1002-1037.

Romer, P.M. 1990. Endogenous technological change. Journal of Political Economy 98 (5): S71-S102.

Sachs, J. D., and Warner, A. M. 1997. Fundamental Sources of Long-Run Growth. The American Economic Review 87 (2): 184-188.
Sala-i-Martin, X., Doppelhofer, G. and Miller, R. I. 2004. Determinants of Long-Term Growth: A Bayesian Averaging of Classical Estimates (BACE) approach. American Economic Review 94 (4): 813-835.

Samuelson, P. A. 1964. Theoretical Notes on Trade Problems. The Review of Economics and Statistics 46 (2): 145-154.

Shaw, E. S. 1973. Financial Deepening in Economic Development. New York, Oxford University Press.

Sidrauski, M. 1967. Inflation and Economic Growth. Journal of Political Economy 75 (6): 796-810.

Snowdon, B. and Vane, H. R. 2005. Modern Macroeconomics: Its origins, development and current state. Edward Elgar, Northampton: Massachusetts.

Solow, R.M. 1956. A Contribution to the Theory of Economic Growth. Oxford Review of Economic Policy 23 (1): 3-14.

Stockman, A. C. 1981. Anticipated Inflation and the Capital Stock in a Cash-in-Advance Economy. Journal of Monetary Economics 8: 387-393.

Stokey, N. L. 1995. R\&D and Economic Growth. The Review of Economic Studies 62 (3): 469-489.

Tobin, J. 1965. Money and Economic Growth. Econometrica 33 (4): 671-684.

World Bank. 1990. Adjustment Lending Policies for Sustainable Growth. Policy and Research Series, Washington D. C., World Bank. 
Table 1: Key Macroeconomic Determinants of Growth in Developing and Developed Countries

\begin{tabular}{|c|c|c|c|}
\hline Author(s) & $\begin{array}{l}\text { Countries and } \\
\text { Sample Period }\end{array}$ & Methodology & Determinants with a Significant Impact on Growth \\
\hline \multicolumn{4}{|c|}{ Developing Countries } \\
\hline Dollar 1992 & $\begin{array}{l}1976-1985 \\
95 \text { developing } \\
\text { economies }\end{array}$ & $\begin{array}{l}\text { Cross-sectional } \\
\text { regression }\end{array}$ & $\begin{array}{l}\text { - Investment rate is positively and significantly associated } \\
\text { with economic growth. } \\
\text { - Real exchange rate variability and real exchange rate dis- } \\
\text { tortions are negatively and significantly associated with } \\
\text { economic growth. }\end{array}$ \\
\hline Fischer 1992 & $\begin{array}{l}\text { Sub-Saharan Africa } \\
\text { and Latin American } \\
\text { and Caribbean } \\
\text { countries; } \\
\text { 1970-1985 }\end{array}$ & $\begin{array}{l}\text { Cross-section } \\
\text { regression }\end{array}$ & $\begin{array}{l}\text { - Human capital, investment, and budget surplus are posi- } \\
\text { tively and significantly associated with economic growth. } \\
\text { - } \quad \text { Initial real GDP and inflation are negatively and significant- } \\
\text { ly associated with economic growth. } \\
\text { - Growth in Sub-Saharan African countries is less than in } \\
\text { Latin America and Caribbean countries }\end{array}$ \\
\hline $\begin{array}{l}\text { Knight, Loayza, } \\
\text { and Villanueva } \\
1993\end{array}$ & $\begin{array}{l}98 \text { countries; } \\
76 \text { developing } \\
\text { countries; } \\
1960-1985\end{array}$ & Panel regression & $\begin{array}{l}\text { - Physical, human capital are positively and significantly as- } \\
\text { sociated with economic growth. } \\
\text { - Public investment is positively and significantly associated } \\
\text { with economic growth. } \\
\text { - Weighted tariff rates are negatively and significantly asso- } \\
\text { ciated with economic growth. }\end{array}$ \\
\hline $\begin{array}{l}\text { Most and Vann } \\
\text { de Berg } 1996\end{array}$ & $\begin{array}{l}11 \text { Sub-Saharan } \\
\text { Africa countries - } \\
\text { Togo, Ivory Coast, } \\
\text { Nigeria, Zambia, } \\
\text { Rwanda, Botswana, } \\
\text { Niger, Senegal, } \\
\text { Mauritius and } \\
\text { Cameroon; (sam- } \\
\text { ple period not } \\
\text { available) }\end{array}$ & $\begin{array}{l}\text { Country-specific } \\
\text { Time series } \\
\text { regression }\end{array}$ & $\begin{array}{l}\text { - } \text { Foreign aid is negatively and significantly associated with } \\
\text { economic growth in Togo, Ivory Coast, Nigeria, Zambia, } \\
\text { Rwanda, and Botswana; and positively and significantly } \\
\text { associated with economic growth in Niger, Senegal and } \\
\text { Mauritius. } \\
\text { - } \text { Domestic savings are positively and significantly associ- } \\
\text { ated with economic growth in Togo, Senegal, Ivory Coast, } \\
\text { Nigeria, Cameroon, and Kenya; and negatively and signifi- } \\
\text { cantly associated with economic growth in Mauritius and } \\
\text { Zambia. } \\
\text { - Foreign Direct Investment is positively and significantly } \\
\text { associated with economic growth in Ivory Coast, Niger, } \\
\text { Kenya and Togo; and negatively and significantly associ- } \\
\text { ated with economic growth in Mauritius and Rwanda. } \\
\text { - Population growth is negatively and significantly associat- } \\
\text { ed with economic growth in Senegal, Mauritius and Niger. }\end{array}$ \\
\hline $\begin{array}{l}\text { Easterly and } \\
\text { Levine } 1997\end{array}$ & $\begin{array}{l}\text { Sub-Saharan Africa } \\
\text { and Latin America } \\
\text { and Caribbean } \\
\text { Countries; } \\
\text { 1960-1980 }\end{array}$ & $\begin{array}{l}\text { Cross-sectional } \\
\text { regression }\end{array}$ & $\begin{array}{l}\text { - The log of schooling, financial depth, a measure of tel- } \\
\text { ephones per worker, and fiscal surplus are positively and } \\
\text { significantly associated with economic growth. } \\
\text { - Political assassinations and black market premiums are } \\
\text { negatively and significantly associated with economic } \\
\text { growth. } \\
\text { - Sub-Saharan African countries and Latin America and } \\
\text { Caribbean countries experienced slow growth compared } \\
\text { to other regions. }\end{array}$ \\
\hline $\begin{array}{l}\text { Hamilton and } \\
\text { Monteagudo } \\
1998\end{array}$ & $\begin{array}{l}98 \text { non-oil countries; } \\
75 \text { intermediate } \\
\text { countries; } \\
22 \text { OECD } \\
1960-1985\end{array}$ & $\begin{array}{l}\text { Ordinary Least } \\
\text { Squares regression } \\
\text { with White (1980) } \\
\text { Heteroskedasticity } \\
\text { - Consistent } \\
\text { standard errors }\end{array}$ & $\begin{array}{l}\text { - The change in output growth is positively associated with } \\
\text { the change in the rate of physical investment. } \\
\text { - The change in output growth is negatively associated with } \\
\text { the change in the rate of population growth. } \\
\text { - An increase in the fraction of resources devoted to edu- } \\
\text { cation is associated with slower (not faster) economic } \\
\text { growth. }\end{array}$ \\
\hline
\end{tabular}




\begin{tabular}{|c|c|c|c|}
\hline Author(s) & $\begin{array}{l}\text { Countries and } \\
\text { Sample Period }\end{array}$ & Methodology & Determinants with a Significant Impact on Growth \\
\hline Barro 1999 & $\begin{array}{l}100 \text { countries (Asia, } \\
\text { Latin America, } \\
\text { OECD, Sub-Saharan } \\
\text { Africa; } \\
\text { 1960-1995 }\end{array}$ & $\begin{array}{l}\text { Panel regression } \\
\text { and three stage } \\
\text { least squares } \\
\text { method }\end{array}$ & $\begin{array}{l}\text { - Investment share, growth rate of terms of trade, years of } \\
\text { schooling, rule of law index, democracy index and interna- } \\
\text { tional openness are positively and significantly associated } \\
\text { with economic growth; } \\
\text { - Government consumption, total fertility rate, and inflation } \\
\text { are negatively and significantly associated with economic } \\
\text { growth. }\end{array}$ \\
\hline $\begin{array}{l}\text { Burnside and } \\
\text { Dollar } 2000\end{array}$ & $\begin{array}{l}56 \text { countries ( } 16 \\
\text { middle-income, } \\
\text { and } 40 \text { low-income } \\
\text { countries); } \\
1970-1993\end{array}$ & $\begin{array}{l}\text { Two-stage least } \\
\text { squares ( } 2 \text { SLS) } \\
\text { method (regres- } \\
\text { sions divided in } \\
\text { six four-year time } \\
\text { periods covering } \\
\text { the years) }\end{array}$ & $\begin{array}{l}\text { - Foreign aid is positively and significantly associated with } \\
\text { economic growth when it enters the growth regression as } \\
\text { an interactive term with policy. } \\
\text { - Budget surplus, institutional quality, trade openness and } \\
\text { countries situated in East Asia are positively and signifi- } \\
\text { cantly associated with economic growth. } \\
\text { - Political assassinations, inflation and countries that are } \\
\text { located in SSA are negatively and significantly associated } \\
\text { with economic growth. }\end{array}$ \\
\hline $\begin{array}{l}\text { Chen and Feng } \\
2000\end{array}$ & $\begin{array}{l}\text { China (29 } \\
\text { provinces); } \\
1978-1989\end{array}$ & $\begin{array}{l}\text { Cross-country ana- } \\
\text { lytical approach }\end{array}$ & $\begin{array}{l}\text { - University enrolment and trade are positively and signifi- } \\
\text { cantly associated with economic growth. } \\
\text { - Inflation and state-owned enterprises are negatively and } \\
\text { significantly associated with economic growth. }\end{array}$ \\
\hline $\begin{array}{l}\text { Radelet, Sachs, } \\
\text { and Whang- } \\
\text { Lee } 2001\end{array}$ & $\begin{array}{l}14 \text { Asian countries; } \\
1965-1990\end{array}$ & $\begin{array}{l}\text { Cross-country } \\
\text { growth framework }\end{array}$ & $\begin{array}{l}\text { - Initial education attainment, coastline distance to land } \\
\text { area, government savings, trade openness, quality of insti- } \\
\text { tutions, life expectancy, growth of working age population } \\
\text { are positively and significantly associated with economic } \\
\text { growth. } \\
\text { - Initial output per worker, natural resource abundance, } \\
\text { landlockedness, location to the tropics are negatively and } \\
\text { significantly associated with economic growth. }\end{array}$ \\
\hline Barro 2003 & $\begin{array}{l}87 \text { countries (devel- } \\
\text { oped and devel- } \\
\text { oping countries); } \\
1965-1995\end{array}$ & $\begin{array}{l}\text { Cross-country } \\
\text { regressions }\end{array}$ & $\begin{array}{l}\text { - Average years of school attainment, investment, rule of } \\
\text { law, democracy, trade openness, and terms of trade are } \\
\text { positively and significantly associated with economic } \\
\text { growth; } \\
\text { - Initial level of per capita GDP, life expectancy, fertility rate, } \\
\text { government consumption, inflation rate and landlocked- } \\
\text { ness are negatively and significantly associated with eco- } \\
\text { nomic growth. }\end{array}$ \\
\hline $\begin{array}{l}\text { Bhaskara-Rao } \\
\text { and Hassan } \\
2011\end{array}$ & $\begin{array}{l}\text { Bangladesh; } \\
\text { 1970-2007 }\end{array}$ & $\begin{array}{l}\text { Neoclassical } \\
\text { growth framework } \\
\text { - ARDL method }\end{array}$ & $\begin{array}{l}\text { - The implementation of reforms since the 1980s, FDI, mon- } \\
\text { ey supply, and trade openness are positively and signifi- } \\
\text { cantly associated with economic growth. } \\
\text { - Government expenditure and inflation are negatively and } \\
\text { significantly associated with economic growth. }\end{array}$ \\
\hline $\begin{array}{l}\text { Chang and } \\
\text { Mendy } 2012\end{array}$ & $\begin{array}{l}36 \text { African countries; } \\
1980-2009\end{array}$ & $\begin{array}{l}\text { Panel fixed effects } \\
\text { regression model }\end{array}$ & 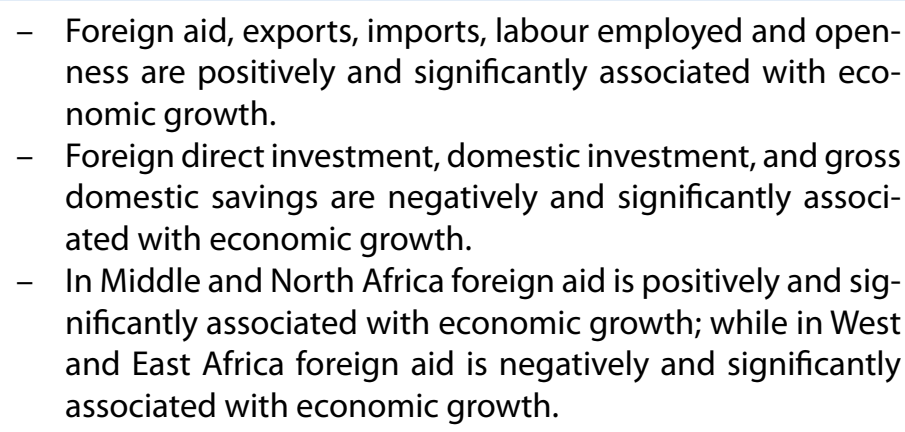 \\
\hline
\end{tabular}




\begin{tabular}{|c|c|c|c|}
\hline Author(s) & $\begin{array}{l}\text { Countries and } \\
\text { Sample Period }\end{array}$ & Methodology & Determinants with a Significant Impact on Growth \\
\hline Anyanwu 2014 & $\begin{array}{l}53 \text { African countries; } \\
\text { 1996-2010 (five } \\
\text { non-overlapping } \\
\text { three-year averages } \\
\text { of cross-sectional } \\
\text { data); Time series } \\
\text { data for China; } \\
\text { 1984-2010 }\end{array}$ & $\begin{array}{l}\text { cross-country } \\
\text { panel regression } \\
\text { for Africa; and } \\
\text { time-series regres- } \\
\text { sion for China }\end{array}$ & $\begin{array}{l}\text { - Africa: higher domestic investment, net official aid, sec- } \\
\text { ondary school enrolment, metal price index, government } \\
\text { effectiveness (governance), and urban population are pos- } \\
\text { itively and significantly associated with economic growth. } \\
\text { - China: domestic investment, and trade openness are posi- } \\
\text { tively and significantly associated with economic growth; } \\
\text { while official development aid, population growth, infla- } \\
\text { tion, credit to the private sector, agricultural material price, } \\
\text { and oil price indices are negatively and significantly associ- } \\
\text { ated with economic growth. }\end{array}$ \\
\hline \multicolumn{4}{|c|}{ Developed Countries } \\
\hline $\begin{array}{l}\text { Bleaney, } \\
\text { Gemmell, and } \\
\text { Kneller } 2001\end{array}$ & $\begin{array}{l}22 \text { OECD countries; } \\
1970-1995\end{array}$ & $\begin{array}{l}\text { Panel estimation: } \\
\text { two-way fixed ef- } \\
\text { fects model }\end{array}$ & $\begin{array}{l}\text { - Investment and productive expenditure are positively and } \\
\text { significantly associated with economic growth. } \\
\text { - Distortionary taxation is negatively and significantly asso- } \\
\text { ciated with economic growth. }\end{array}$ \\
\hline $\begin{array}{l}\text { Freire-Seren } \\
2002\end{array}$ & $\begin{array}{l}\text { Spain (Spanish } \\
\text { Regions); 1964-1991 }\end{array}$ & $\begin{array}{l}\text { Augmented neo- } \\
\text { classical growth } \\
\text { model }\end{array}$ & $\begin{array}{l}\text { - Human capital and investment are positively and signifi- } \\
\text { cantly associated with economic growth. }\end{array}$ \\
\hline Anaman 2004 & $\begin{array}{l}\text { Brunei Darussalam; } \\
\text { 1971-2001 }\end{array}$ & $\begin{array}{l}\text { Augmented neo- } \\
\text { classical growth } \\
\text { model }\end{array}$ & $\begin{array}{l}\text { - Exports and investment share are positively and signifi- } \\
\text { cantly associated with economic growth. } \\
\text { - Government size exhibits threshold effects where moder- } \\
\text { ate government size has a positive and significant asso- } \\
\text { ciation with growth - and higher government size has a } \\
\text { negative and significant association with growth. }\end{array}$ \\
\hline $\begin{array}{l}\text { Acikgoz and } \\
\text { Mert } 2005\end{array}$ & $\begin{array}{l}3 \text { Asian countries; } \\
\text { Time series data } \\
\text { (Taiwan, 1951-2007; } \\
\text { Korea, 1953-2007; } \\
\text { and Hong Kong, } \\
\text { 1960-2007) }\end{array}$ & $\begin{array}{l}\text { ARDL and FMOLS } \\
\text { methods }\end{array}$ & $\begin{array}{l}\text { - Short-run results: investment share is positively and sig- } \\
\text { nificantly associated with economic growth. } \\
\text { - Long-run results: investment is positively and significantly } \\
\text { associated with the level of real GDP per capita. }\end{array}$ \\
\hline Bayraktar 2006 & Turkey; 1968-1998 & $\begin{array}{l}\text { Extreme Bounds } \\
\text { Analysis }\end{array}$ & $\begin{array}{l}\text { - Investment share and human capital have a robust posi- } \\
\text { tive and significant association with economic growth. } \\
\text { - In terms of monetary indicators, the study found a robust } \\
\text { negative and significant relationship between inflation } \\
\text { and growth. }\end{array}$ \\
\hline $\begin{array}{l}\text { Asheghian } \\
2009\end{array}$ & Japan; 1971-2006 & $\begin{array}{l}\text { Augmented } \\
\text { neoclassical } \\
\text { growth model - } \\
\text { Beach-Mackinnon } \\
\text { technique }\end{array}$ & $\begin{array}{l}\text { - The growth rate of total factor productivity and the growth } \\
\text { rate of domestic investment are positively and significant- } \\
\text { ly associated with economic growth. }\end{array}$ \\
\hline $\begin{array}{l}\text { Checherita- } \\
\text { Westphal and } \\
\text { Rother } 2012\end{array}$ & $\begin{array}{l}12 \text { Euro countries; } \\
1970-2008\end{array}$ & $\begin{array}{l}\text { Conditional con- } \\
\text { vergence equation }\end{array}$ & $\begin{array}{l}\text { - Government balance, government debt, private savings, } \\
\text { and trade openness are positively and significantly associ- } \\
\text { ated with economic growth. } \\
\text { - Population growth, the square of government debt and } \\
\text { real interest rates are negatively and significantly associ- } \\
\text { ated with economic growth. }\end{array}$ \\
\hline \multicolumn{4}{|c|}{ South-East and Central European Countries } \\
\hline $\begin{array}{l}\text { Botric and } \\
\text { Slijepcevic } \\
2008\end{array}$ & $\begin{array}{l}6 \text { South-Eastern } \\
\text { European countries; } \\
1995-2005\end{array}$ & $\begin{array}{l}\text { Panel Fixed Effects } \\
\text { Regression }\end{array}$ & $\begin{array}{l}\text { - Inflation and interest rate spread are negatively and sig- } \\
\text { nificantly associated with economic growth. } \\
\text { - General government balance as a share of GDP is positive- } \\
\text { ly and significantly associated with economic growth }\end{array}$ \\
\hline
\end{tabular}




\begin{tabular}{|c|c|c|c|}
\hline Author(s) & $\begin{array}{l}\text { Countries and } \\
\text { Sample Period }\end{array}$ & Methodology & Determinants with a Significant Impact on Growth \\
\hline $\begin{array}{l}\text { De Grauwe and } \\
\text { Schnabl } 2008\end{array}$ & $\begin{array}{l}18 \text { South-Eastern } \\
\text { and Central } \\
\text { European countries; } \\
1994-2004\end{array}$ & $\begin{array}{l}\text { Panel Fixed Effects } \\
\text { Regression }\end{array}$ & $\begin{array}{l}\text { - Exchange rate stability against the Euro and exchange rate } \\
\text { stability against the Euro and US Dollar are negatively and } \\
\text { significantly associated with economic growth. } \\
\text { - Growth rate of dollar exports and budget deficit as a share } \\
\text { of GDP are positively and significantly associated with eco- } \\
\text { nomic growth. }\end{array}$ \\
\hline Prochniak 2011 & $\begin{array}{l}10 \text { Central and } \\
\text { Eastern European } \\
\text { countries; } \\
1993-2009\end{array}$ & $\begin{array}{l}\text { Ordinary Least } \\
\text { Squares }\end{array}$ & $\begin{array}{l}\text { - investment rate, human capital development, financial } \\
\text { sector development, high services share in GDP, high share } \\
\text { of working age population, development of information, } \\
\text { communication and technology (ICT), high private sector } \\
\text { share in GDP, economic freedom, and progress in market } \\
\text { and structural reforms are positively and significantly as- } \\
\text { sociated with economic growth } \\
\text { - Budget deficits, public debt, interest rates, and inflation } \\
\text { are negatively and significantly associated with economic } \\
\text { growth. }\end{array}$ \\
\hline $\begin{array}{l}\text { Fetahi-Vehapi, } \\
\text { Sadiku, and } \\
\text { Petkovski } 2015\end{array}$ & $\begin{array}{l}10 \text { South East } \\
\text { European countries; } \\
1996-2012\end{array}$ & $\begin{array}{l}\text { Panel Fixed Effects } \\
\text { regression }\end{array}$ & $\begin{array}{l}\text { - Trade openness, initial level of GDP per capita, human cap- } \\
\text { ital development, gross fixed capital formation, foreign di- } \\
\text { rect investment are positively and significantly associated } \\
\text { with economic growth. } \\
\text { - Population is negatively and significantly associated with } \\
\text { economic growth. }\end{array}$ \\
\hline
\end{tabular}

